\title{
Factors Affecting Capital Expenditure Allocation: Empirical Evidence from Regency/City Government in Indonesia
}

\author{
Ilham Maulana Saud ${ }^{1 *}$, Eka Asterina ${ }^{2}$, and Gisti Fairuz Trisha ${ }^{3}$
}

\begin{abstract}
:
Research aims: To analyze the effect of local taxes, regional retribution, special allocation fund, and area size on the allocation of capital expenditure with economic growth as a moderating variable in the regency/city Governments in Indonesia from 2016 to 2017.

Design/Methodology/Approach: This study used secondary data obtained through the website of the Ministry of Home Affairs, Ministry of Finance, and Audit Board of the Republic of Indonesia. Based on the purposive sampling method, a sample of 565 regencies/cities in Indonesia was obtained. The hypothesis testing in this study used Moderated Regression Analysis.

Research findings: Based on the results of the study, it could be concluded that partially the local tax variables, special allocation fund, and area had a positive and significant effect on capital expenditure allocation. In contrast, regional retribution variables did not affect capital expenditure allocation, and economic growth could moderate the effect of local tax on capital expenditure allocation, but unable to moderate the effect of regional regional on capital expenditure allocations.

Theoretical contribution/Originality: This research proved the theory of fiscal federalism in the relationship to fiscal decentralization, such as local taxes, economic conditions, public services, and public welfare. Moreover, this study enriched the literature on the application of the theory of stewardship in government agencies.

Practitioner/Policy implication: Regional governments in regencies/cities in Indonesia are expected to explore the potential of their regions better so that they can improve the steward function to the community.

Research limitation/Implication: The research period was relatively short; due to the availability of data only from 2016 to 2017, many research data were outliers. Future research is expected to renew the observation period and change the intervening model, as well as add other variables related to capital expenditure, such as General Allocation Funds (DAU), Revenue Sharing Funds (DBH), population numbers, Budget Surplus (SILPA) and others.

Keyword: Regional Taxes; Regional Retribution; Special Allocation Fund; Area; Capital Expenditures; Economic Growth
\end{abstract}

AFFILIATION:

1, 2, 3 Department of Accounting, Faculty of Economics and Business, Universitas Muhammadiyah Yogyaarta, Daerah Istimewa Yogyakarta, Indonesia.

\section{*CORRESPONDENCE:}

ilhamsaud@umy.ac.id

THIS ARTICLE IS AVAILABLE IN:

http://journal.umy.ac.id/index.php/ai

DOI: 10.18196/jai.2102150

\section{CITATION:}

Saud, I. M., Asterina, E., \& Trisha, G. F. (2020). Factors Affecting Capital Expenditure Allocation: Empirical Evidence in Regency / City Government in Indonesia. Journal of Accounting and Investment, 21(2), 289-311.

\section{ARTICLE HISTORY}

Received:

4 March 2020

Reviewed:

6 April 2020

Revised:

25 Apr 2020

Accepted:

27 April 2020

\section{Introduction}

Minister of Home Affairs Regulation No. 13 of 2006 concerning Guidelines for Regional Financial Management states that regional government expenditure consists of indirect and direct expenditure. Indirect 
expenditure is a budget that is not directly related to the implementation of programs and activities. In contrast, direct expenditure is an expenditure that is budgeted directly for the implementation of various programs and activities, such as capital expenditure, employee expenditure, and expenditure for goods and services.

In Indonesia, a fiscal decentralization policy has been put in place since 2001. Fiscal decentralization is the transfer of authority from the central government to regional governments (Bodman, Heaton, \& Hodge, 2009). In the current era of fiscal decentralization, the implementation of regional autonomy is significant (Kusuma, 2016). Based on Law Number 32 of 2004, regional autonomy is the right and obligation of an autonomous region to independently manage the government and the interests of the community in accordance with applicable regulations. The implementation of regional autonomy focuses on regencys and cities marked by the transfer of authority from the central government to regional governments. The expected benefits in the implementation of regional autonomy are that it can increase the potential of the region so that it can provide improved services to the public in various sectors, especially in the public sector (Kusnandar \& Siswantoro, 2009).

Malik, Ul-hassan, and Hussain (2006) stated that a country's fiscal decentralization is one effective strategy to enhance economic growth and development. Jaya and Dwirandra (2014) also stated that the implementation of regional autonomy in the era of fiscal decentralization is focused on optimally developing regional development so that economic growth and community welfare increase.

Regional development can be implemented because of capital expenditure allocations. Capital expenditure is an expenditure that will add a fixed asset for public services that benefit more than one year (Government Regulation of the Republic of Indonesia Number 71 of 2010). Capital expenditure budget is obtained from regional revenue funds, but these funds are not only allocated for capital expenditure but also are allocated for other regional expenditures. Based on his study, Felix (2012) states that the allocation of regional expenditures is allocated more for routine expenditure (goods and services expenditure) and employee expenditures whose benefits are less productive for public services because these expenditures are only enjoyed by local officials. The rest is, only a small portion of it, used for capital expenditure. To overcome this, the regional government must be wiser in allocating regional expenditure, especially in the allocation of capital expenditure (Nugraha \& Dwirandra, 2016). The following data is the realization of regional expenditure on regencies/cities in Indonesia from 2016 to 2017, which is shown in Figure 1.

Based on the Minister of Home Affairs Regulation (Permendagri) No.37 / 2012 that the Regional Government is required to allocate a minimum capital expenditure of $29 \%$ of regional expenditure. The specific phenomena that occur in the regency/city local government in Indonesia in 2016 to 2017 local governments can only allocate capital expenditure of $22 \%$ of regional spending. The figure 1 shows if the realization of capital expenditure is dominated by personnel expenditure with a percentage of $38.50 \%$ and $40 \%$, then capital expenditure is $21.81 \%$ and $22 \%$, goods, and services expenditure is 
$18.74 \%$ and $21 \%$ respectively, while the rest was for other expenditure which reached $21 \%$ and $16 \%$. From this phenomenon, it can be concluded that regional governments have not been able to reach the minimum allocation of capital expenditure as stipulated in the Minister of Home Affairs Regulation No. 37/2012, because the regional expenditure of regency/city Indonesia was allocated more on the employee expenditure.

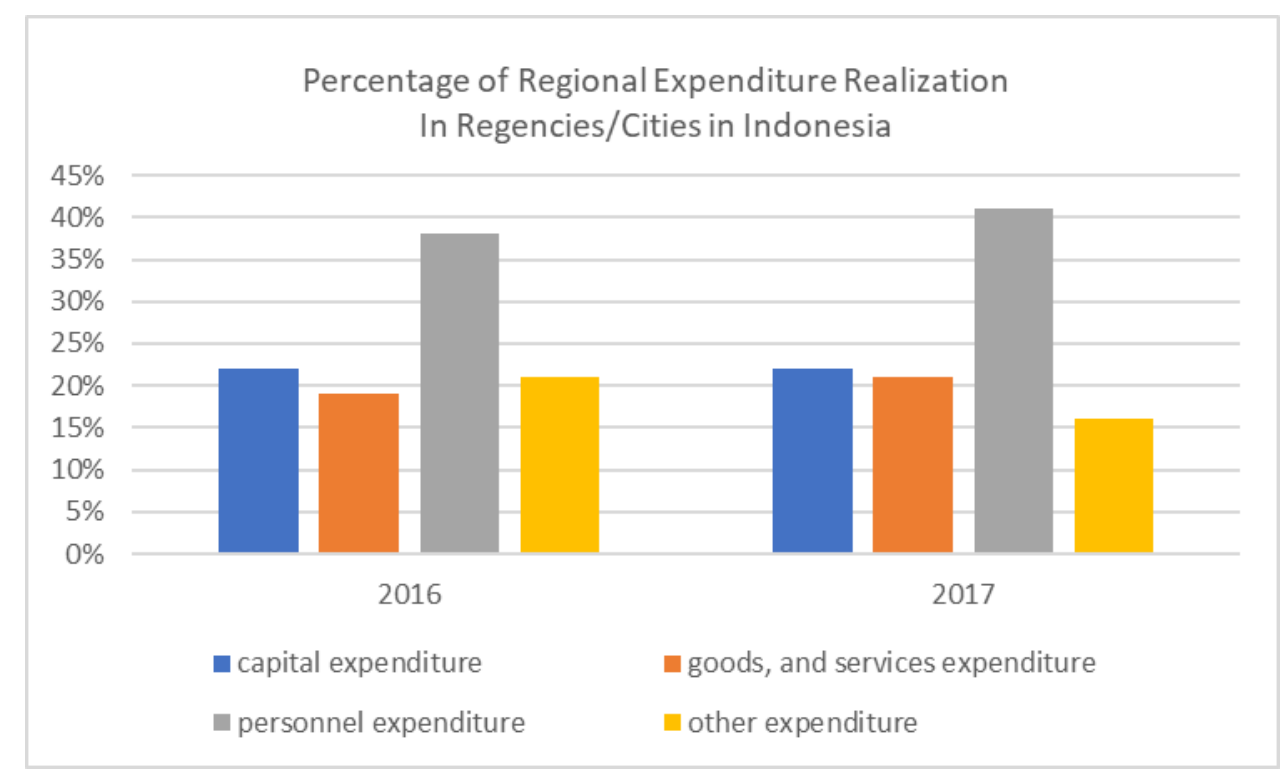

Figure 1 Realization of Regional Expenditure

Source: Regency/city governments financial statistics

Capital expenditure budget is based on public needs for public facilities and infrastructure. It is stated in Law Number 32 Year 2004 that the source of original regional income comes from local taxes, regional retribution, and other valid regional income. Law No. 28/2009 on regional taxes and regional retribution, explains that local taxes are contributions from individuals or entities to local governments that are mandatory and compelling and do not get direct compensation from their payments. Nevertheless, the results of the regional tax payments are used for the regional needs and prosperity of the people.

Land and Building taxes received from infrastructure development, such as housing, have a direct impact on the enhancement of local tax. This kind of tax payment will help to increase public participation in the development of public infrastructure for the advancement and welfare of the community, because the higher the local tax received, the higher the capital expenditure allocation will be. Results of research conducted by Rahmawati and Tjahjono (2018) proved that local taxes had a positive effect on the allocation of capital expenditure, the study is in line with research in the previous year conducted Sudika and Budiartha (2017), and Lestari (2015). However, the research undertaken by Handayani, Abdullah, and Fahlevi (2015) showed different results, which indicated that local taxes did not affect the allocation of capital expenditure. 
Based on Law No. 34 of 2000, regional retribution is regional user charge as payments for particular services or permits that are specifically provided by local governments for the benefit of individuals or entities. Hence, regional retribution is the full responsibility of the local government. As a result, the government must provide adequate services so that the community believes in the services offered by the local government. According to Sudika and Budiartha (2017), regional retribution is classified as one of the sources of Original Local Government Revenue that is useful for financing regional development and administration. Results of research conducted by Nugraha and Dwirandra (2016) and Ramlan, Abdullah, and Darwanis (2016) showed that regional retribution had a positive effect on the allocation of capital expenditure. It is different from the research conducted by Rahmawati and Tjahjono (2018) which the result indicated that regional had not affected sigficantly on the cpital expenditure.

The unequal regional financial potential will lead to fiscal gaps between the central government and local governments which can result in development differences between regions (Hairiyah, Malisan, \& Fakhroni, 2017). herefore, to reduce disparities and support the implementation of regional autonomy through the provision of funding sources, Law Number 33 of 2004 concerning Financial Balance between the Central Government and Regional Governments was issued. Based on Law number 33 of 2004 and Government Regulation number 55 of 2005, the balance fund consists of the General Allocation Fund (DAU), the Special Allocation Fund (DAK), and the Revenue Sharing Fund (DBH).

Special allocation fund is fund allocated to regions with specific objectives for investment development activities, improvement, and improvement of public facilities and infrastructure with a long economic life. The existence of a special allocation fund is expected to increase the allocation of capital expenditure because theoretically, the special allocation fund aims for development that will add to the physical assets of the local government (Andrian \& Samekto, 2017). The results of the study conducted by Hairiyah et al. (2017) showed that special allocation funds had a positive influence on capital expenditure, which in line with the studies conducted by Pratama (2017), Juniawan and Suryantini (2018). On the other hand, the research by Ayem and Pratama (2018) indicated that the special allocation fund did not affect capital expenditure allocation.

Capital expenditure allocation is based on regional needs for facilities and infrastructure of each region, promptness, and comfort of public facilities. Based on Law Number 33 of 2004 , one of the variables that reflects the need for the provision of facilities and infrastructure is the area size. The area size in this study covers all regencies/cities in Indonesia, where the area between regions has a different size so that the need for facilities and infrastructure owned is different as well. The researcher is interested in examining whether the difference in area size will affect the amount of capital expenditure allocation (Kusnandar dan Siswantoro, 2009). The research of Putra (2017) showed that the area size had a positive effect on capital expenditure, which is in accordance with the studies conducted by Wibisono and Wildaniati (2016), as well as 
Sholikah and Wahyudin (2014). However, Widiasmara (2019) found that the area size did not affect the capital expenditure.

Economic growth illustrates better community conditions with an increase in community productivity. Therefore, economic growth is a process of increasing national income continuously in the long run so that the level of consumption and productivity of the population increases (Jaeni, 2016). The higher the national income of a country, the more likely the country has a high level of development and the average income of the population because economic growth is an indication of the success of economic development. The government can improve the welfare of the community through increased economic growth, for example, by improving infrastructure, health services, increasing education, and increasing production in the service sector and capital goods (Sukirno, 2011). This study used economic growth as a moderating variable to see whether economic growth can strengthen or weaken the relationship between regional taxes and regional retribution towards capital expenditure allocations. The result of the study conducted by Nugraha and Dwirandra (2016), showed that economic growth could strengthen the effect of regional tax and regional retribution towards capital expenditure allocation.

This study aims to empirically examine the effect of regional taxes, regional retribution, special allocation fund, area size, and economic growth on the allocation of capital expenditure regencies/cities in Indonesia in 2016-2017. The motivation to carry out this study is because, in 2016-2017, the regional government had not yet reached the minimum capital expenditure allocation limit as stipulated in the Minister of Home Affairs Regulation No. 37 of 2012. Besides, the results of the capital expenditure allocation study still did not show consistency, and the research sample coverage only focused on one province/city/region (Nugraha \& Dwirandra, 2016; Hairiyah et al., 2017; Sudika and Budiartha, 2017; Ayem and Pratama, 2018; Putra, 2017; Wibisono \& Wildaniati, 2016).

It is expected that this study contributes to providing input for local governments related to strategies to achieve the minimum capital expenditure allocation provisions by optimizing regional tax revenues and regional retribution. The results of this study also provide a high level of generalization because it uses data from all regencies/cities in Indonesia.

\section{Literature Review and Hypotheses Development}

\section{Stewardship Theory}

Stewardship theory is a theory that describes a situation where management does not prioritize individual interests but instead prioritizes the importance of the organization (Davis, 1997). This theory explains the relationship between satisfaction and organizational success. Organizational success illustrates the maximum achievement in 
the principal and management groups that can help the performance of individual interests in organizational groups.

Stewardship theory can be applied to research in public sector organizations such as government (Vosselman, 2016: Lofgren, Macaulay, Berman, \& Plimmer 2017). Public sector accounting can help government agencies to meet the information needs between stewards and principals. Government management has the responsibility of providing services for the interests of the principal (community). Thus, the management in the government environment acts more dominantly as a steward than as an agent or intermediary.

The application of the theory of stewardship in this research is to explain the role of local government as a trustworthy institution to serve the public interest in carrying out their duties and responsibilities appropriately, make financial reports to achieve the target of economic goals, public services, and public welfare to the maximum, such as capital expenditure used for the public interest. To carry out these responsibilities, the stewards (local government) must control internal interests to produce quality financial information reports.

\section{Fiscal Federalism Theory}

The theory of fiscal federalism elaborates on a general normative framework for the assignment of functions to various levels of government and appropriate financial instruments to carry out government functions. At the broadest level, this theory argues that the central government delegates authority to lower-level governments (Oates, 1972 in Oates 1999). The delegation of authority is in the form of fiscal decentralization policy.

The correlation of fiscal federalism theory in this study illustrates the relationship between decentralization as well as regional taxes and regional retribution with the economy, public services, and public welfare (Sari \& Supadmi, 2016). The existence of fiscal decentralization policy in Indonesia, which delegates the management of regional taxes and regional retribution independently, is expected to improve regional development. It includes economic growth, creating competent human resources in all fields, utilization of natural data sources, in which those aspects aim to enhance the welfare of the community.

\section{The Effect of Regional Taxes on Capital Expenditure Allocation}

Fiscal decentralization gives authority to the regions to independently manage government and the interests of the people in accordance with applicable laws, which aim to improve regional independence and public welfare. Local Own-Source Revenue (PAD) is a benchmark for the implementation of fiscal decentralization because PAD is the primary source of local government funding, one of which is a local tax. Local taxes make a considerable contribution to local own-source revenue because local taxes are 
the most potential alternative in increasing state revenues; this is because taxes have a relatively stable amount. Sudika and Budiartha (2017) explained that spending on infrastructure development had an impact on increasing local tax revenues. Besides, the regional tax payment is compulsory and forced in accordance with applicable laws, so that it will make the public aware and concerned to carry out its state obligations. To explore the potential of local taxes can be done through extensification and intensification policies. The intensification policy is in the form of an increase in regional tax sources, which is carried out by giving guidance to taxpayers to increase awareness and compliance of taxpayers, while the extensification policy is in the form of extracting local tax potential by adding the number of unregistered taxpayers (Christover \& Rondonuwu, 2016).

The local tax aims to realize regional independence; the more independent an area will result in higher regional expenditure allocations, especially in capital expenditure (Nurhidayati \& Yaya, 2013). Harefa, Permana, Mangeswuri, and Meilani (2017) also argued that Local tax revenue is used for governance and regional development. Capital expenditure budget is used to facilitate the needs of the community so that the community will prosper, in accordance with the objectives of the stewardship theory, that stewards try to serve the community so that their needs are fulfilled. The results of the study by Rahmawati and Tjahjono (2018) in regencies/cities in the Special Province of Yogyakarta showed that local taxes had a positive and significant effect on the allocation of capital expenditure. This study is supported by the research of Sudika and Budiartha (2017) in regencies/cities in Bali province, as well as the study conducted by Lestari (2015) on the city governance in West Java, in which the result of the study indicated that regional taxes had a positive influence on capital expenditure. Based on the previous elaboration, the first hypothesis on this study is:

$\boldsymbol{H}_{1}$ : Regional taxes have a positive effect on capital expenditure allocation.

\section{The Effect of Regional Retribution on Capital Expenditure Allocation}

Stewardship theory focuses on working hard in realizing the interests of the organization and prioritizing the need to develop (Alderfer, 1972). The relation to regional retribution is that the acceptance of regional retribution is based on the service of granting permits/services provided by the government to individuals/bodies, the higher the community's need for regional retribution services, it will increase the revenue of regional retribution on Local Own-Source Revenue (PAD) so that the ability of local governments to allocate expenditure capital is also high (Nugraha \& Dwirandra, 2016). To maximize services for regional retribution, the government must improve facilities and services for regional retribution such as tourism places, cleanliness, and public facilities, for instance, markets, terminals, roadside parking, and other permits.

Each region determines tariffs and management on regional retribution under applicable laws, so the more effective and efficient. The services that the government provides will increase the revenue of regional retribution. Moreover, the burden 
incurred by local governments on public services for regional retribution is getting lower. Besides that, the provision of goods and appropriate services that individuals/agencies want for regional service fees is also essential because excellent services foster a sense of trust in individuals/bodies. As a result, individuals/agencies will continue to use regional service fees.

The studies conducted by Nugraha and Dwirandra (2016) on regencies/cities in Bali, Ramlan et al. (2016) in regencies/cities in Aceh showed that regional retribution had a positive effect on the capital expenditure allocation because it is believed that is essential in supporting services and community needs. Based on the previous elaboration, then the second hypothesis of this study is:

\section{$\boldsymbol{H}_{2}$ : Regional retribution has a positive effect on capital expenditure allocation}

\section{The Effect of Special allocation fund on Capital Expenditure Allocation}

Special allocation fund is part of a balanced fund. Balance funds are funds sourced from State Budget (APBN) revenues, which are then allocated to the regions to fund regional needs in the context of implementing decentralization. The purpose of allocating special allocation fund in accordance with the objectives of the stewardship theory is that they both aim to create adequate public services because local governments do not prioritize individual interests, but rather prioritize the importance of the organization (Davis, 1997).

Special allocation fund is used to finance special activities such as investment development activities, improvement, and improvement of physical facilities and infrastructure of public services that must be borne by the government. These special funds are expected to be able to make a real contribution to infrastructure development. In terms of the unique nature, these funds are significant because of various development investment programs that also carry out overtime must be fulfilled; the role of special allocation fund (DAK) is increasing. Therefore, the higher the receipt of special allocation funds will help improve the allocation of capital expenditure. It is because a special allocation fund (DAK) is a special grant fund, in which its distribution is used as infrastructure development that has been determined from the center. Hence, the realization of a special allocation fund (DAK) is the realization of capital expenditure. Nuryadin and Suharsih (2017) elaborated that the allocation of a special allocation fund increases considerably over time. Most of the enhancement is from the allocation of a special allocation fund (DAK) for regencies/cities.

The studies conducted by Juniawan dan Suryantini (2018) in regencies/cities in Bali, Hairiyah et al. (2017) regencies/cities in East Borneo, and Pratama (2017) regencies/cities in Riau, showed that special allocation fund had a positive effect on capital expenditure allocation. Based on the previous explanation, the third hypothesis is as follows: 
Factors Affecting Capital Expenditure Allocation: Empirical Evidence ...

$\boldsymbol{H}_{3}$ : Special allocation fund has a positive effect on capital expenditure allocation

\section{The effect of Area Size on Capital Expenditure Allocation}

Based on the stewardship theory, the government is trusted to serve the interests of the community by carrying out its duties and functions appropriately, so that the economic goals, services, and welfare of the community can be achieved optimally.

Allocating capital expenditure based on regional needs for public facilities and infrastructure is both for the smooth implementation of government tasks and for adequate public facilities. Following Law Number 33 of 2004, the area is one of the variables that describe the need for the provision of facilities and infrastructure. It means that the larger the area size in a region, the more facilities, and infrastructure that must be provided by local governments. As a result, there will be an excellent public service because the government has a great responsibility to help facilitate all the needs of local communities. Associated with the New Autonomous Region (DOB), the results of regional expansion try to provide adequate public service facilities, especially in hospitals, schools, telecommunications towers, highways, bridges, markets, and others. Therefore, the more extensive a region is, the more public infrastructure development must be fulfilled. As a consequence, the higher the capital expenditure allocation that must be budgeted. In other words, the area size is closely related to the capital expenditure allocation. The results of the studies by Putra (2017) in regencies/cities in West Sumatra province, Wibisono and Wildaniati (2016) in regencies/cities in East Java province, as well as Sholikah and Wahyudin (2014) regencies/cities in Java, indicated that area size had a positive influence on capital expenditure allocation. Based on the elaboration above, the fourth hypothesis is:

$\boldsymbol{H}_{4}$ : Area size has a positive effect on capital expenditure allocation

\section{Economic Growth Moderates the Effect of Regional Taxes on Capital Expenditure Allocation}

The theory of fiscal federalism correlates between fiscal decentralization, such as local taxes with economic conditions, as well as various public services and public welfare (Sari \& Supadmi, 2016). Economic growth is the process of increasing the production of goods and services in the commercial activities of the society. This enhancement can be seen from the growing production of industrial products and capital goods, developing infrastructure, and growing service sector, etc.

Economic growth is considered to strengthen the relationship between regional taxes and capital expenditure allocations. As a result of higher economic growth, local taxes and capital expenditure allocations can increase as well. It is because high economic growth illustrates better community life along with improving society's income. Hence, the consumption and productivity of the community grow too. Good economic growth is 
also represented by the high construction of industrial infrastructures such as restaurants, housing, and others. Besides, the enhancement of the community's economic growth will help to boost investments in the region because investors will not be worry about financing in areas that have good economic growth with various ease of access, such as regulations or public facilities provided by the government. This condition will have an impact on the ability of the community to pay taxes that have been required by the government and can increase the allocation of regional capital expenditure due to improved regional income from taxes. Therefore, economic growth can strengthen the relationship of regional taxes with the allocation of regional capital expenditure, which eventually will be used as infrastructure improvements for public services.

The result of the study conducted by Nugraha and Dwirandra (2016) in regencies/cities in Bali province showed that economic growth could moderate the effect of regional taxes on capital expenditure allocation. Based on the explanation previously, the fifth hypothesis is as follows:

$\boldsymbol{H}_{5}$ : Economic growth can moderate the effect of regional taxes on capital expenditure allocation.

\section{Economic Growth Moderates the Effect of Regional Retribution on Capital Expenditure Allocation}

Regional retributions differ from local taxes because they have direct rewards that can be enjoyed by the payer. In addition to local taxes, the theory of fiscal federalism also correlates fiscal decentralization, such as regional retribution, with economic conditions, as well as various public services and public welfare (Sari \& Supadmi, 2016).

The acceptance of regional retributions is based on the service of granting permits/services provided by the government to individuals/bodies the higher the community's need for regional retribution services, will increase the revenue of regional retribution. As a result, the ability of local governments to allocate capital expenditure also improves (Nugraha \& Dwirandra, 2016). Economic growth is considered to strengthen the relationship between regional retribution and capital expenditure allocations. Higher economic growth can increase local retribution and capital expenditure allocations. It is because high economic growth illustrates a better community life with high income earned by the community resulting in increased consumption and productivity of the community. The higher the level of economic growth, it is expected that the community needs more and more interests for regional retribution services. It means that the region will get income from these services and can increase the allocation of regional capital expenditure because regional revenue from regional retribution enhances. Therefore, economic growth can strengthen the relationship between the receipt of regional retribution with the allocation of regional capital expenditure, which will later be used as infrastructure improvements for public services. 
The studies conducted by Nugraha and Dwirandra (2016) in regencies/cities in Bali province showed that economic growth could moderate the effect of regional retribution on capital expenditure. Based on the previous explanation, the sixth hypothesis in this study is:

$\boldsymbol{H}_{6}$ : Economic growth can moderate the effect of regional retribution on capital expenditure allocation.

\section{Research Method}

This study included all regencies/cities in Indonesia as population. The sampling technique used in this study was purposive sampling, which is a sampling technique using certain criteria. The sampling criteria in this study were; first, the regency/city government in the Indonesian Province in 2016 and 2017, and all regencies/cities sampled have published and audited Regional Revenue and Expenditure Budget (RVEB) realization, economic growth data, and complete area data (see Table 1). Data are obtained from the Report on Realization of Regional Revenue and Expenditure Budget (RVEB) on www.djpk.kemenkeu.go.id. Report on Gross Domestic Product (GRDP) on the website of https://www.bps.go.id/, and the data of area size from the website of https://www.kemendagri.go.id.

Table 1 Research Sample

\begin{tabular}{lc}
\hline Sample Criteria & Sample \\
\hline Regencies/cities government of provinces in Indonesia (2016-2017) & 1.016 \\
Regencies/cities government that published or audited the realization of & $(50)$ \\
Regional Revenue and Expenditure Budget (RVEB), data of economic growth, \\
$\begin{array}{l}\text { and incomplete data of area size (2016-2017) } \\
\text { Number of sample data used and processed }\end{array} \quad 966$ \\
$\begin{array}{l}\text { The number Data (abnormal) } \\
\text { The sample data processed }\end{array}$ & 565 \\
\hline
\end{tabular}

Source: Results of Secondary Data Processing, 2019

The dependent variable in this study is capital expenditure. Government Regulations Number 71 Year 2010 explains that capital expenditure is a regional government expenditure that benefits more than one fiscal year, which will add to the fixed assets or wealth of an area. The independent variables of this study were regional taxes, regional retribution, special allocation fund, and area size. The definition of local tax based on Law Number 28 Year 2009 is compulsory contributions to regions by individuals or entities without the presence of a balanced direct reward for payments, and payments can be forced under applicable laws. Whereas regional retributions, according to Law Number 28 Year 2009, are regional retributions as payments for services or specific permits that are specifically provided by local governments for the benefit of individuals/entities. Special allocation fund variable based on Government Regulations No. 55 of 2005 is a fund allocated explicitly to specific regions to help special fund activities in an area following national priorities. The area based on Government Regulation Number 47 of 1997 is a space that is a geographical unit and all elements 
whose boundaries and systems are determined based on administrative and functional aspects. The size of the area is measured using the $\mathrm{km}^{2}$ unit.

The moderating variable in this study is economic growth. Economic growth is a process of an output increase per capita (Boediono, 2009). The economic growth in the regency/city is proxied using the rate of economic growth based on constant prices in 2010.

All variables in this study used a logarithmic scale by rounding up nominal values that were too large. The use of logarithms is to smooth the magnitude of numbers and equalize the size of the research data. It aims to avoid data errors during regression testing (Risty, 2014).

The hypothesis testing in this study used Moderated Regression Analysis (MRA). MRA is used to determine the effect of local taxes, regional retribution, special allocation fund, and area size on the allocation of capital expenditure with economic growth as a moderating variable.

\section{Result and Discussion}

\section{Descriptive Statistical Analysis}

In this study, all research variables in the form of dependent, independent, and moderation variables use a logarithmic scale to round up nominal values that are too large (Risty, 2014). The descriptive statistical analysis test aims to present information about the amount of data in the study, the minimum value, maximum, mean, and standard deviation. The overall descriptive statistical test results are presented in the following table 2 .

Table 2 Results of Descriptive Statistical Analysis

\begin{tabular}{lc|c|ccc}
\hline & N & Min & Max & Mean & Std. Dev. \\
\hline Capital expenditure & 565 & 11.05 & 12.49 & 11.4442 & 0.15323 \\
Regional taxes & 565 & 8.57 & 13.16 & 10.3464 & 0.57981 \\
Regional retribution & 565 & 8.10 & 11.12 & 9.8461 & 0.50374 \\
Special allocation fund (DAK) & 565 & 10.78 & 12.85 & 11.2897 & 0.20706 \\
Area size & 565 & 1.21 & 4.55 & 3.1776 & 0.64817 \\
Economic growth & 565 & -1.10 & 1.05 & 0.7223 & 0.14625 \\
Valid N (listwise) & 565 & & & & \\
\hline
\end{tabular}

Source: Results of data processing SPSS 26.0

Table 2 illustrates descriptive statistics on the variables used in this study. The table 2 shows there are 565 numbers of data used in the study. Within two years, the dependent variable (capital expenditure) obtained a standard deviation of 0.15323 and an average of 11.44442 or equal to $22 \%$. The average value of capital expenditure of $22 \%<29 \%$ shows that the allocation of capital expenditure in total regional spending in regencies/cities in Indonesia is still relatively low. The region that has the highest capital 
expenditure is Bangkalan Regency in 2017 with a capital expenditure logarithm of 12.49 or $3,090,055,683,753$ IDR, while the area with the lowest capital expenditure is Banggai Laut Regency in 2016, with a logarithm value of capital expenditure of 11.05 or $112,449,756,310$ IDR.

Within two years, the independent variable (Log_regional tax) shows a standard deviation of 0.57981 and an average of 10.3464. It indicates that the average contribution of regional taxes in total regional original income for regencies/cities in Indonesia is 10.3464. The region that has the highest local tax is Bangkalan Regency in 2017 with a regional tax logarithm of 13.16 or $14,350,601,626,319$ IDR. On the other hand, the area that has the lowest local tax is Puncak Jaya Regency in 2017, with a local tax logarithm value of 8.57 or $368,138,060$ IDR.

During two years, the independent variable (regional Log_retribution) obtained a standard deviation of 0.50374 and an average of 9.88461. It shows that the average contribution of regional retribution in total regional original income to regencies/cities in Indonesia is 9.88461. The regions that have the highest regional regional are Bangkalan Regency in 2017, with a logarithm of the regional retribution of 11.12 or $131,444,291,907$ IDR. On the other hand, the region that has the lowest regional retribution is the Waropen Regency in 2016, with a logarithm of the regional retribution of 8.10 or $124,784,000$ IDR.

In two years, the independent variable (Log_special allocation fund) shows a standard deviation value of 0,20706 , and an average of 11.2897. The average value of 11.2897 indicates that the most significant proportion in this study lies in the variable special allocation fund, so it can be said that regional dependence on the central government is still high. The region with the highest special allocation fund is Bangkalan Regency in 2017 , with a logarithm of special allocation fund of 12.85 or $7,056,095,687,317$ IDR. As the Regency of Wondama Bay in 2017 has the lowest special allocation fund with a logarithm of special allocation fund of 10.78 or $60,156,861,789$ IDR.

During two years, the independent variable (Log_area size) indicates a standard deviation of 0.64817 and an average of 3.1776. The logarithm of the average area of 3.1776 , means that the average area of each regency/city in Indonesia reaches $3,455,4200 \mathrm{~km} 2$. The region with the highest area is West Kutai Regency with a logarithm value of 4.55 or $35,696.59 \mathrm{~km} 2$, while the region with the lowest area is Magelang City with a logarithm of 1.21 or 16, 06.

Within two years, the moderating variable (Log_economic growth) obtained a standard deviation of 0.14625 , and the average economic growth reached 0.7223 ( $72.23 \%)$. So it can be concluded that the average economic growth that can be achieved by regencies/cities in Indonesia is $72.23 \%$. The maximum value of 1.05 is found in Central Halmahera Regency in 2016, and the minimum value of -1.10 is located in Indramayu Regency in 2016.

\section{Classic assumption test}


The classic assumption test is a mandatory requirement for multiple linear regression analysis. Before testing the hypothesis, the data is first assessed with the classic assumption test to produce an unbiased regression model, because not all regression data can be processed. The results of the classical assumption test showed that the regression model used in this study was normally distributed and free from symptoms of autocorrelation, multicollinearity, and heteroscedasticity.

\section{Research Results and Discussion}

Based on the results of hypothesis testing in Table 3, they showed that the variables of local taxes, special allocation fund, and area size had a positive effect on the allocation of capital expenditure. At the same time, regional retribution did not affect the allocation of capital expenditure. Furthermore, economic growth variables could moderate the effect of regional taxes on capital expenditure allocations, but could not moderate the impact of regional retribution on capital expenditure allocations.

\section{Effect of Local Taxes on Capital Expenditure Allocation}

The first hypothesis in this study is that local tax has a positive effect on the allocation of capital expenditure $\left(\mathrm{H}_{1}\right)$. The results of hypothesis testing for local tax variables showed a sig value of $0,000<0.05$ and a coefficient value of 0.103 , so that $\left(\mathrm{H}_{1}\right)$ is supported. Local taxes are part of the original local revenue, which is the primary source of funding for local governments. Even though each region has unequal local tax revenue potential, this study with a sample that covers all regencies/cities in Indonesia proved that local taxes affected the allocation of capital expenditure because local taxes are the most potential alternative in increasing state revenue. It is because the tax has a relatively stable amount; for example, the land and building tax in which each year the taxpayer is subjected to pay for the land and building tax for each asset owned. Besides, the regional tax payment is compulsory and forced under the applicable laws, so that people become more aware and concerned to carry out their state obligations.

The higher local tax revenue will result in higher capital expenditure allocations. It is proved by the results of descriptive statistical analysis, which showed the maximum value of local taxes in Bangkalan regency in 2017 and the maximum value of capital expenditure in Bangkalan Regency in 2017. Based on Law No. 28 of 2009 that local taxes are used for people's prosperity, and local taxes are used for state financing and national development by allocating these taxes to capital expenditure. Harefa et al. (2017) also stated that regional tax revenues are used to finance governance and regional development, which is realized in capital expenditure. Capital expenditure budget is used to facilitate the needs of the community in fulfilling regional public facilities and infrastructure for the creation of a prosperous society, in accordance with the objectives of the stewardship theory that stewards strive to serve the community so that their needs are met. Basically, local taxes are revenue sourced from the community and one of the potential possessed by the region, so the community plays as an interested party in the implementation of development. Therefore, local taxes must continue to be explored to create the welfare of the community itself. 
Table 3 Results of Hypothesis Test Model 1 and 2

\begin{tabular}{|c|c|c|c|c|c|c|}
\hline \multicolumn{2}{|c|}{ Model } & \multicolumn{2}{|c|}{$\begin{array}{l}\text { Unstandardized } \\
\text { Coefficients }\end{array}$} & $\begin{array}{c}\text { Standardized } \\
\text { Coefficients } \\
\text { Beta }\end{array}$ & $\mathrm{t}$ & Sig \\
\hline \multirow[t]{8}{*}{1} & (Constant) & 5.166 & 0.152 & & 34.017 & 0.000 \\
\hline & Regional Tax & 0.103 & 0.007 & 0.390 & 14.520 & 0.000 \\
\hline & Regional Retribution & - & 0.008 & -0.020 & -0.788 & 0.431 \\
\hline & & 0.006 & & & & \\
\hline & Special allocation fund & 0.465 & 0.016 & 0.628 & 28.244 & 0.000 \\
\hline & Area Size & 0.038 & 0.005 & 0.161 & 7.940 & 0.000 \\
\hline & Economic Growth & - & 0.018 & -0.132 & -7.498 & 0.000 \\
\hline & & 0.138 & & & & \\
\hline \multirow[t]{8}{*}{2} & (Constant) & 5.086 & 0.151 & & 33.745 & 0.000 \\
\hline & Regional Tax & 0.028 & 0.033 & 0.107 & 0.850 & 0.396 \\
\hline & Regional Retribution & 0.083 & 0.35 & 0.274 & 2.370 & 0.018 \\
\hline & Special allocation fund & 0.463 & 0.016 & 0.625 & 28.195 & 0.000 \\
\hline & Area Size & 0.039 & 0.005 & 0.165 & 8.149 & 0.000 \\
\hline & Regional Tax*Economic Growth & 0.105 & 0.045 & 1.087 & 2.319 & 0.021 \\
\hline & Regional Retribution*Economic & - & 0.048 & -1.231 & -2.603 & 0.009 \\
\hline & Growth & 0.125 & & & & \\
\hline
\end{tabular}

Source: Results of Data Processing SPSS 26.0

The results of this study were in line with the research by Rahmawati and Tjahjono (2018) in regencies/city in Special Region of Yogyakarta province, Sudika and Budiartha (2017), Nugraha and Dwirandra (2016) in regencies/cities in Bali province, as well as Lestari (2015) in government city in West Java province, which elaborated that regencies/cities governments had worked well in exploring sources of regional income from the side of local tax revenue.

\section{The Effect of Regional Retribution on Capital Expenditure Allocation}

The second hypothesis in this study is that regional retribution has a positive effect on the allocation of capital expenditure $\left(\mathrm{H}_{2}\right)$. The results of hypothesis testing for regional retribution variables showed a sig value of $0.431>0.05$ and a coefficient value of -0.006 , so that $\left(\mathrm{H}_{2}\right)$ was not supported. Such conditions illustrate that regional retribution did not affect the allocation of capital expenditure. It can occur because the service fees of each regency/city in Indonesia are different since the natural resources owned by one region to another also differ. Besides that, the setting regional retribution tariffs are also determined by each region under applicable law and regulation, so that these significantly affect the size of the level of regional retribution revenue in the regencies/cities in Indonesia.

The results of this study proved that not all regencies/cities at local governments in Indonesia maximize services for their regional retribution, thereby causing low regional retribution. It is proved by the highest value of regional retribution of only $131,444,291,907$ IDR. At the same time, the local tax reaches $14,350,601,626,319$, IDR. Hence, the lower the level of revenue from regional retribution, the allocation of capital expenditure will also be lower (decreasing), which in the end, the revenue from regional 
retribution does not become the main funding source in the allocation of capital expenditure in regencies/cities in Indonesia.

In contrast to regional taxes, the emphasis of regional retribution is the direct reward that can be enjoyed by the community. However, in reality, there are still many complaints from the public over the service fees provided by the local government. There is still a mismatch between the fees paid and the quality of services received. Therefore the community does not want to pay higher if the service received is still poor quality. Moreover, it will also eliminate the sense of public trust in local governments, which will result in people feel reluctant to use the services of regional retribution.

The results of this study are supported by the research conducted Handayani et al. (2015) in regencies/cities in Aceh province, Mamonto, Kalangi, and Tolosang (2015) in Bolaang Mongondow regency, Sudika and Budiartha (2017) in regencies/cities in Bali province. Handayani et al. (2015) stated that regional retribution did not affect the capital expenditure because there was an assumption that the community considered regional retribution as a part of a program, not as the regional income. Therefore, the community would pay if the level of service was maintained and improved.

Sudika and Budiartha (2017) also stated that the reason for regional retribution did not have a positive effect on capital expenditure because the management of regional revenue sources has not been managed properly so that the contribution of regional retribution revenue in the original regional revenue proportion is still low. Although Bali Island is famous for its tourism, so many tourists come to Bali, and of course, it will cause an increase in revenue on tourism retribution. Still, it is not able to increase revenue on regional retribution revenue because the management provided by local governments on the island of Bali is not maximized and is not in line with management that can increase the proportion of regional retribution. In this case, the progress or failure of an area is very much determined by the willingness and ability of the regional government to run their region without violating the statutory provisions.

\section{The Effect of Special allocation fund on Capital Expenditure Allocation}

The third hypothesis in this study is the special allocation fund has a positive effect on the allocation of capital expenditure $\left(\mathrm{H}_{3}\right)$. The results of hypothesis testing for special allocation fund variables show a sig value of $0,000<0.05$ and a coefficient value of 0.465 , so that $\left(\mathrm{H}_{3}\right)$ is supported. Based on Law No. 33 of 2004, special allocation fund are funds intended to finance special activities in a particular region in accordance with national priorities. This special activity leads to investment activity, such as the improvement of public facilities and infrastructure with a long economic life.

The Special Allocation Fund is significant because various development investment programs must be fulfilled over time, then the role of the special allocation fund is increasing. Therefore, the higher the special allocation fund, the greater the capital expenditure allocation is. It is proved by the results of descriptive statistical analysis, 
which shows the maximum value of special allocation fund found in Bangkalan regency in 2017 and the maximum value of capital expenditure in Bangkalan Regency in 2017.

Special allocation fund are transfer funds sourced from the central government to assist local governments in developing and prospering their people through proportional and professional regional wealth management and building sustainable infrastructure. Local governments can use Special allocation fund to provide services to the public that are realized through capital expenditure. Special allocation fund are given to finance special activities on public service facilities and infrastructure that have not yet reached the standard in regional development (Hairiyah et al., 2017). Basically, the Special Allocation Fund is a special grant fund, determined from the central government that its designation is for infrastructure development. Therefore, the realization of a special allocation fund is the realization of capital expenditure. This research proved that the central government had met the minimum requirements of at least $10 \%$ of special allocation fund intended for regencies /cities of local governments in Indonesia, and the regencies /cities had used the special allocation fund to finance programs and activities correctly and in accordance with what is needed by the society, so that the role of steward in serving the needs of principals has been achieved.

The results of this study are in line with the research conducted by Hairiyah et al. (2017) in regencies/cities in East Borneo province, Pratama (2017) in regencies/cities in Riau province, Juniawan and Suryantini (2018) in regencies/cities in Bali province which showed that special allocation fund had a positive effect on capital expenditure.

\section{The effect of Area Size on Capital Expenditure Allocation}

The fourth hypothesis of this study is that the area size has a positive effect on the allocation of capital expenditure $\left(\mathrm{H}_{4}\right)$. The results of hypothesis testing for the area size variables show a sig value of $0,000<0.05$ and a coefficient value of 0.038 , so that $\left(\mathrm{H}_{4}\right)$ is supported. The area size variable in this study covers all regencies/cities in Indonesia, where the area between one region and another has an unequal size, so the need for facilities and infrastructure owned by one region to another is also different. The results from this research proved that areas that have a wider size resulted in higher capital expenditure. That is because large areas require more facilities and infrastructure. The infrastructure development must be extensively improved to create excellent public service, and social inequality does not occur between regions that have more extensive areas compared to regions that have smaller areas (Meianto, Betri, \& Wenny, 2014). For instance, areas that have a wider area will require the construction of a highway, which is larger than the area that has a small area. In this case, the regencies/cities of regional government have carried out its duties in accordance with the theory of stewardship, where the government is believed can serve the public interest by carrying out its duties and functions appropriately so that public welfare and adequate public services can be achieved.

In accordance with Law Number 33 of 2004, the area size is one of the variables that describe the need for the provision of facilities and infrastructure. More specifically, 
when it is related to the New Autonomous Region (DOB), the results of the regional expansion attempt to provide adequate public service facilities, especially in hospitals, schools, telecommunications towers, highways, bridges, markets, and others.

The results of this study were in line with the research by Putra (2017)in regencies/cities in West Sumatra province, Wibisono and Wildaniati (2016) in regencies/cities in East Java province, Sholikah and Wahyudin (2014) in regencies/cities in Java island, Meianto et al. (2014)in regencies/cities in South Sumatra, which stated that area size had a positive effect on the capital expenditure allocation.

\section{Economic Growth Moderates the Effect of Regional Taxes on capital Expenditure Allocation}

The fifth hypothesis of this study is economic growth can moderate the effect of local taxes on the allocation of capital expenditure $\left(\mathrm{H}_{5}\right)$. Hypothesis testing results for the variable regional taxes interaction with economic growth shows a sig value of 0.021 $<0.05$ and a coefficient value of 0.105 , so that $\left(H_{5}\right)$ is supported. Such conditions illustrate that economic growth has a vital role in affecting the increased regional taxes on capital expenditure allocations. It is supported by the theory of fiscal federalism, which states that there is a relationship between fiscal decentralization such regional taxes with economic conditions, as well as various public services and public welfare (Sari \& Supadmi, 2016).

Since economic growth is a process of increasing the production of goods and services in economic activities of the community, meaning that economic growth illustrates a better community life with high income earned by the community, then the level of consumption and productivity of the population increases. Furthermore, when regency/city governments have good economic growth, the construction of industrial infrastructures such as hotels, restaurants, housing, and others will be even higher. Increasing economic growth in a region has an impact on improving people's income and enhancing infrastructure development, which in turn, will also affect the high allocation of regional capital expenditure sourced from regional taxes due to increased regional tax revenue.

Besides that, the improvement of economic growth can enhance the investors to invest in the regions (Jaeni, 2016). It is because investors do not feel apprehension about investing in areas where economic growth is good with various ease of access, such as regulations or public facilities provided by the government. Therefore, the better the level of economic growth in regencies/cities in Indonesia, the higher the allocation of capital expenditure sourced from local taxes.

The results of this study are in line with the research conducted by Nugraha and Dwirandra (2016) in Bali province, which stated that economic growth could moderate the effect of regional taxes on capital expenditure allocation. 


\section{Economic Growth Moderated the Effect of Regional Retribution on Capital Expenditure Allocation}

The sixth hypothesis of this study proposes that economic growth can moderate the effect of regional retribution on capital expenditure allocation $\left(\mathrm{H}_{6}\right)$. The results of hypothesis testing for the interaction variables of regional retribution with economic growth show a sig value of $0.009<0.05$ and a coefficient value of -0.125 , so that $\left(\mathrm{H}_{6}\right)$ is not supported. Previously, a hypothesis test had been done for the regional retribution variable, in which the results suggested that regional retribution did not affect capital expenditure. After being re-tested using the moderating variable, the results continued to state that economic growth was not able to moderate the effect of regional retribution on capital expenditure allocation.

The higher level of economic growth is not able to strengthen the influence of regional retribution on capital expenditure due to several factors. First, the regional service fees for each regency/city in Indonesia are different because the natural resources owned by one region with other regions are different as well. Besides, the stipulation of regional retribution tariffs is determined by each region in accordance with the applicable laws, so that it greatly influences the level of acceptance of regional retribution in the regencies/cities of local government in Indonesia despite high economic growth rates. Local governments have not been able to take advantage of opportunities for economic growth to maximize the management of regional retribution. This condition can cause a low allocation of regional capital expenditure due to the lack of revenue from regional retribution. Second, good economic growth without a balance, by boosting the regional service fees, will result in revenue retribution, which remains low. The public definitely will not use local service fees if the services provided by the government are still inadequate and not in accordance with the wishes of the community even though the level of consumption and productivity increases. For instance, based on research data in 2016 Central Halmahera regency has the highest economic growth of 11.24, but the receipt of its regional retribution amounted to 5,730,499,945 IDR, in contrast to North Halmahera regency with total revenue from its regional retribution amounted to $28,909,730,628$ IDR, with the economic growth of 4.03 .

\section{Conclusion}

The results of this study confirmed the fiscal federalism theory which states that there is a relationship between fiscal decentralization such as local taxes with economic conditions, as well as various public services and public welfare. It is proven by the support of economic growth that could strengthen the relationship of regional taxes on capital expenditure. In addition, the results of this study also showed that regional taxes, special allocation fund, and area size were essential factors in the allocation of capital expenditure to meet the obligations of regency/city governments to carry out their functions optimally as community stewards. 
This research implies that the regional governments in regencies/cities in Indonesia are expected to be more able to explore the potential of the region, especially on regional retribution. Increasing regional retribution will make local governments more independent in funding all regional needs, especially in capital expenditure, and in turn, it can improve the quality of services to the community.

There are some limitations to this study. First, the research period is relatively short due to the availability of data only from 2016 to 2017. Secondly, several numbers of research data are outliers. As for the suggestions given by the author to improve further research, it is expected that the next researchers will add a more extended observation period and change the intervening model in their study. Second, new research is also expected to be able to combine other variables related to capital expenditure, such as General Allocation Funds (DAU), Revenue Sharing Funds (DBH), population numbers, Budget Surplus (SILPA) and others.

\section{References}

Alderfer, C. P. (1972). Existence, relatedness, and growth. Human needs in organizational settings. New York: US. Free Press.

Andrian, Y., \& Samekto, A. (2017). Pengaruh Pendapatan Asli Daerah (PAD), Dana Alokasi Umum (DAU), dan Dana Alokasi Khusus (DAK) Terhadap Alokasi Belanja Modal Pada Kabupaten / Kota di Pulau Jawa. Journal of Accounting Research and Review, 10(2), 139-152. Retrieved from http://jurnal.unsyiah.ac.id/TRA/article/view/14018/10609

Ayem, S., \& Pratama, D. (2018). Pengaruh Pertumbuhan Ekonomi, Dana Alokasi Umum, Dana Alokasi Khusus dan Pendapatan Asli Daerah Terhadap Belanja Modal di Provinsi Daerah Istimewa Yogyakarta Periode 2011-2016. Akuntansi Dewantara, 2(2), 169-182. http://dx.doi.org/10.26460/ad.v2i2.2987

Bodman, P., Heaton, K.A., \& Hodge, A. (2009). Fiscal Decentralisation and Economic Growth: A Bayesian Model Averaging Approach. School of Economics, The University of Queensland, December, 1-10. Retrieved from http://www.uq.edu.au/economics/mrg/3509.pdf

Boediono. (2009). Teori Pertumbuban Ekonomi. Edisi ketujuh. Yogyakarta: BPFE.

Christover, A. P., \& Rondonuwu, S. (2016). Pemahaman Ekstensifikasi Wajib Pajak Dan Intensifikasi Pajak Terhadap Persepsi Fiskus Tentang Penerimaan Pajak. Jumal EMBA, 4(1), 1241-1253. https://doi.org/10.35794/emba.v4i1.12294

Davis, J. H. (1997). Toward A Stewardship Theory Of Management. Academy of Management Review, 22(1), 20-47. https://doi.org/10.2307/259223

Felix, O. (2012). Analysis of the effectiveness of capital expenditure budgeting in the local government system of Ondo State, Nigeria. Journal of Accounting and Taxation, 4(1), 1-6. https://doi.org/10.5897/JAT11.038

Hairiyah, Malisan, L., \& Fakhroni, Z. (2017). Pengaruh dana alokasi umum DAU dana alokasi khusus DAK dan pendapatan asli daerah PAD terhadap belanja modal, Journal FEB Unmul, 14(2), 85-91. http://dx.doi.org/10.29264/jkin.v14i2.2483

Handayani, S., Abdullah, S., \& Fahlevi, H. (2015). Pengerauh Penerimaan Pajak Daerah, Retribusi Daerah dan Dana Bagi Hasil (DBH) terhadap belanja modal di Kabupaten/Kota Di Provinsi Aceh. Journal Magister Akuntansi Pascasarjana Universitas 
Syiah Kuala, 4(2), 45-50. Retrieved from

http://www.jurnal.unsviah.ac.id/JAA/article/view/4467/3846

Harefa, M., Permana, S. M., Mangeswuri, D. R., \& Meilani. H. (2017). Optimalisasi

Kebijakan Penerimaan Daerah (Kerjasama Yayasan Pustaka Obor Indonesia-Bidang

Ekonomi dan Kebijakan Publik Pusat Penelitian Badan Keahlian DPR RI. Ed. 1, Cet.

1, Jakarta. Retrieved from https://berkas.dpr.go.id/puslit/files/buku tim/buku-timpublic-77.pdf

Jaeni, G. A. L. (2016). Pertumbuhan Ekonomi Sebagai Variabel Pemoderasi Pendapatan Asli Daerah Dan Bantuan Provinsi Terhadap Belanja Modal. Dinamika Akuntansi, Kenangan dan Perbankan, 5(1), 13-26. Retrieved from https://www.unisbank.ac.id/ojs/index.php/fe9/article/view/5569/1693

Jaya, I. P., \& Dwirandra, A. A. N. B. (2014). Pengaruh Pendapatan Asli Daerah Pada Belanja Modal dengan Pertumbuhan Ekonomi Sebagai Variabel Pemoderasi. E-Jurnal Akuntansi Universitas Udayana, 7(1), 79-92. Retrieved from https://ojs.unud.ac.id/index.php/Akuntansi/article/view/8643/6440

Juniawan, M. A., \& Suryantini, N. P. S. (2018). Pengaruh Pad, Dau Dan Dak Terhadap Belanja Modal Kota Dan Kabupaten Di Provinsi Bali. E-Jurnal Manajemen Universitas Udayana, 7(3), 1255-1281. https://doi.org/10.24843/EJMUNUD.2018.v7.i03.p05

Kusnandar, \& Siswantoro, D. (2009). Pengaruh Dana Alokasi Umum, Pendapatan Asli Daerah, Sisa Lebih Pembiayaan Anggaran dan Luas Wilayah terhadap Belanja Modal. Jurnal Universitas Indonesia, 1-20. Retrieved from https://scholar.google.co.id/citations? user=r3CdU2AAAAAJ\&hl=en

Kusuma, H. (2016). Desentralisasi Fiskal dan Pertumbuhan Ekonomi di Indonesia. Jurnal Ekonomi Kuantitatif Terapan, 9(1), 1-11. https://doi.org/10.24843/JEKT.2016.v09.i01.p01

Lestari, S. A. P. (2015). Pengaruh Penerimaan Pajak Daerah terhadap Belanja Modal Daerah pada Pemerintahan Kota di Jawa Barat Tahun 2011-2013. E-Proceeding of Management, 2(3), 3383-3392. Retrieved from

https://openlibrary.telkomuniversity.ac.id/pustaka/files/104615/jurnal eproc/penga ruh-penerimaan-pajak-daerah-terhadap-belanja-modal-daerah-pada-pemerintahankota-di-jawa-barat-tahun-2011-2013.pdf

Lofgren, K., Macaulay, M., Berman, E., \& Plimmer, G. (2017). Expectations, Trust, and 'No Surprises': Perceptions of Autonomy in New Zealand Crown Entities. Australian Journal of Public Administration, 77(4), 672-684. DOI:10.1111/1467-8500.12305

Malik, S., Ul-hassan, M., \& Hussain, S. (2006). Fiscal Decentralization and Economic Growth in Pakistan. Department of Economics, Bahauddin Zakariya University, Multan, Pakistan. Retrieved from https://www.jstor.org/stable/41260655

Mamonto, S. Y., Kalangi, \& D. Tolosang, K. (2015). Pengaruh Pajak Daerah dan Retribusi Daerah Terhadap Belanja Modal. Jurnal Berkala Ilmiah Efisiensi, 15(1), 1-14. Retrieved from https://ejournal.unsrat.ac.id/index.php/jbie/article/view/6377/5894

Meianto, E., Betri, \& Wenny, C. D. (2014). Pengaruh Dana Alokasi Umum, Dana Alokasi Khusus, Pendapatan Asli Daerah, dan Luas Wilayah Terhadap Belanja Modal Pada Kabupaten/Kota Di Sumatera Selatan. STIE Multi Data Palembang, 1-13. Retrieved from http://eprints.mdp.ac.id/1472/1/Jurnal\%20Edy\%20Meianto\%202011210030.pdf

Nugraha, I. P., \& Dwirandra, A. A. N.B . (2016). Kemampuan Pertumbuhan Ekonomi Memoderasi Pengaruh Pajak Daerah, Retribusi Daerah, DAU dan DBH pada Belanja Modal. E-Jurnal Akuntansi Universitas Udayana, 14(1), 284-311. Retrieved from https://ojs.unud.ac.id/index.php/Akuntansi/article/view/14408/11843 
Nurhidayati, L. L., \& Yaya, R. (2013). Alokasi belanja modal untuk pelayanan publik: praktik di pemerintah daerah. Jurnal Akuntansi \& Auditing Indonesia, 17(2), 102-114. https://doi.org/10.20885/jaai.vol17.iss2.art2

Nuryadin, D., \& Suharsih, S. (2017). Analisis dan Evaluasi Dampak Dana Alokasi Khusus terhadap Indikator Kinerja Pembangunan di Daerah, Studi Kasus Kabupaten-Kota 2003/2013. Jurnal Ekonomi Dan Studi Pembangunan, 18(1), 62-70. https://doi.org/10.18196/jesp.18.1.3954

Oates, Wallace, E. (1999). An Essay on Fiscal Federalism. Journal of Economic Literature, 37(3), 1120-1149. Retrieved from https://www.jstor.org/stable/i344067

Peraturan Direktur Jenderal Perbendaharaan. Nomor Per- 33 /pb/2008 Tentang Pedoman Penggunaan Akun Pendapatan, Belanja Pegawai, Belanja Barang, Dan Belanja Modal.

Peraturan Menteri Dalam Negeri No.13 Tahun 2006 tentang Pedoman Pengelolaan Keuangan Daerah.

Peraturan Menteri Keuangan Nomor 101/PMK.02/2011 Tentang Klasifikasi Anggaran.

Peraturan Mentri Dalam Negeri No.37/2012 Tentang Pedoman Penyusunan Anggaran Pendapatan dan Belanja Daerah Tahun Anggaran 2012

Peraturan Pemerintah Republik Indonesia Nomor 47 Tahun 1997 Tentang Rencana Tata Ruang Wilayah Nasional.

Peraturan Pemerintah Republik Indonesia Nomor 55 Tahun 2005 Tentang Dana Perimbangan.

Peraturan Pemerintah Republik Indonesia Nomor 71 Tahun 2010 Tentang Standar Akuntansi Pemerintahan.

Pratama, R. (2017). Pengaruh Pendapatan Asli Daerah, Dana Alokasi Umum, Dana Alokasi Khusus Terhadap Alokasi Belanja Modal dengan Pertumbuhan Ekonomi Sebagai Variabel Moderasi. JOM Fekon, 4(1), 2677-2689. Retrieved from https://jom.unri.ac.id/index.php/JOMFEKON/article/view/19502/18849

Putra, F. (2017). Pengaruh desentralisasi fiskal, luas wilayah, dan sisa lebih pembiayaaan anggaran terhadap pengalokasian belanja modal. Article Universitas Negeri Padang, 1-25. Retrieved from http://ejournal.unp.ac.id/students/index.php/akt/article/view/2418/1927

Rahmawati, R., \& Tjahjono, A. (2018). Pengaruh Pajak Daerah, Retribusi Daerah, Dana Alokasi Umum, Dan Dana Alokasi Khusus Terhadap Belanja Modal Di D.I Yogyakarta Tahun 2012 - 2016. Jurnal Kajian Bisnis, 26(2), 195-209. Retrieved from http://jurnal.stieww.ac.id/index.php/ikb/article/view/124/106

Ramlan, Abdullah, S., \& Darwanis. (2016). Pengaruh Pajak Daerah, Retribusi Daerah, LainLain Pendapatan Asli Daerah yang Sah, dan Dana Alokasi Khusus terhadap Belanja Modal. Jurnal Magister Akuntansi, 5(2), 79-88. Retrieved from http://www.jurnal.unsyiah.ac.id/JAA/article/view/4512/3888

Risty, N. N. (2014). Pengaruh Ukuran Perusahaan, Aktiva Tetap, dan Future Abnormal Earnings Terhadap Kebijakan Utang. Jurnal Telaah \& Riset Akuntansi, 7(1), 22-28. Retrieved from http://jurnal.unsyiah.ac.id/TRA/article/view/10131/8003.

Sari, I., \& Supadmi, N. L. (2016). Pengaruh Pendapatan Asli Daerah dan Belanja Modal pada Peningkatan Indeks Pembangunan Manusia. E-Jurnal Akuntansi Universitas Udayana, 15(3), 2409-2438. Retrieved from https://ojs.unud.ac.id/index.php/Akuntansi/article/view/16283/13972

Sholikah, I., \& Wahyudin, A. (2014). Analisis Belanja Modal pada Pemerintah Kabupaten/Kota di Jawa. Accounting Analysis Journal, 3(4), 553-562. https://doi.org/10.15294/aaj.v3i4.4224

Sudika, I., \& Budiartha, I. K. (2017). Pengaruh Pajak Daerah, Retribusi Daerah, Dana Alokasi Umum, dan Dana Alokasi Khusus Pada Belanja Modal Provinsi Bali. E-Jurnal 
Saud, Asterina, \& Trisha

Factors Affecting Capital Expenditure Allocation: Empirical Evidence ...

Akuntansi Universitas Udayana, 21(2), 1689-1718.

https:// doi.org/10.24843/EJA.2017.v21.i02.p30

Sukirno, S. (2011). Makro Ekonomi Teori Pengantar Edisi Ketiga. Jakarta: Rajawali Pers.

Suparmoko. (2002). Ekonomi Publik (Untuk Kenangan dan Pembangunan Daerah), Yogyakarta: Penerbit Andi.

Undang-Undang Republik Indonesia Nomor 28 Tahun 2009 Tentang Pajak Daerah dan Retribusi Daerah.

Undang-Undang Republik Indonesia Nomor 32 Tahun 2004 Tentang Pemerintahan Daerah.

Undang-Undang Republik Indonesia Nomor 33 Tahun 2004 Tentang Perimbangan Keuangan antara Pemerintah Pusat dan Pemerintahan Daerah.

Undang-Undang Republik Indonesia Nomor 34 Tahun 2000 Tentang Perubahan atas Undang-Undang Republik Indonesia Nomor 18 Tahun 1997 Tentang Pajak Daerah dan Retribusi Daerah.

Vosselman, E. (2016). Accounting, Accountability, and Ethics in Public Sector Organizations. Administration \& Society, 48(5),602-627. https://doi.org/10.1177/0095399713514844.

Wibisono, N., \& Wildaniati, A. (2016). Pengaruh Pertumbuhan Ekonomi, PAD, DAU, SiLPA dan Luas Wilayah Terhadap Alokasi Anggaran Belanja Modal. Journal Ekomaks, 5(2), 11-20. Retrieved from http://unmermadiun.ac.id/ejurnal/index.php/ekomaks/article/view/212/412

Widiasmara, A. (2019). Pengaruh Pendapatan Asli Daerah, Dana Alokasi Khusus, Dana Alokasi Umum, Total Aset dan Luas Wilayah, terhadap Belanja Modal dengan Pertumbuhan Ekonomi sebagai Variabel Moderating. Journal of Islamic Finance and Accounting, 2(1), 45-56. https://doi.org/10.22515/jifa.v2i1.1594

Yudiaatmaja, F., Suwendra, W., \& Sukmawati, R. (2016). Pengaruh Pendapatan Asli Daerah Dan Sisa Lebih Pembiayaan Anggaran Terhadap Belanja Modal Pada Pemerintah Daerah Kabupaten Buleleng. E-Journal Bisma Universitas Pendidikan Ganesha, 4, 1-9. Retrieved from https://ejournal.undiksha.ac.id/index.php/JMI/article/viewFile/6680/4541 